Article

\title{
Sustainable Environments in Education: Results on the Effects of the New Environments in Learning Processes of University Students
}

\author{
Diego Galán-Casado, Alvaro Moraleda *(D), María Luisa Martínez-Martí(i) and \\ Miguel Ángel Pérez-Nieto \\ Faculty of Education and Health, Camilo José Cela University, 28692 Madrid, Spain; dagalan@ucjc.edu (D.G.-C.); \\ mmmarti@ucjc.edu (M.L.M.-M.); mperez@ucjc.edu (M.Á.P.-N.) \\ * Correspondence: amoraleda@ucjc.edu
}

Received: 26 February 2020; Accepted: 26 March 2020; Published: 28 March 2020

\begin{abstract}
Within the framework of the Sustainable Development Goals, it is necessary to move towards quality education that promotes opportunities based on the principles of equity and equality. For this reason, the environment where the teaching-learning process occurs plays a fundamental role. Our research shows the results of the effects of the environment in the learning processes of university students $(\mathrm{N}=33)$. Using a method of sampling experiences, the students assessed how the new environment learning (NEL) compared to the traditional classroom (TC) encouraged their attention, participation in class, creativity, curiosity, critical thinking, motivation to learn and mood (hedonic tone and activation level). In addition, the students assessed to what extent the class seemed visually appealing to them. The design was of repeated measures, so that the experiences of the same subjects in both classrooms were evaluated over a period of 53 days. Over this period of time, after finishing each of the classes selected for the study, the participants received a message on their mobile phones with a link to a short ad hoc questionnaire that evaluated their experience in relation to the learning environment of the classes they had just attended. In total, we recorded 359 responses in relation to the TC and 209 in relation to the NEL. The results show statistically significant differences in the degree of participation and visual appeal, with higher levels in the NEL. These elements are vital in achieving the education for sustainable development, oriented towards critical thinking, responsibility and social transformation.
\end{abstract}

Keywords: sustainable environments; new environments learning; sustainable development goals; learning processes; experience sampling method; physical environment

\section{Introduction}

Today's society, shaped by information and knowledge, requires understanding education as an integral process through which students acquire skills, capabilities, expertise and attitudes that lead to effective processes of social inclusion. This is one of the aims of the 2030 Agenda for Sustainable Development, reflected in its fourth goal, which calls for equitable quality education that enables not only improved standards of living through the teaching-learning process, but also ensures the process becomes a tool that helps to provide innovative solutions to the major issues facing our society [1].

This new approach to education, encapsulated in the 2030 Agenda for Sustainable Development, should guide students' instruction process to teach them how to live in society [2]. Education is one of the main resources of personal and professional development. It favours the acquisition of the tools required for social engagement [3] and avoids the processes of exclusion that bar people from a life of wellbeing $[4,5]$ and hinder their ability to transform society. 
In order to achieve these goals and purposes, we need agencies, organisations and corporations to take charge of the implementation and dissemination of formal education, over and above voluntary projects or other types of activities of an informal nature, which often constitute the main initiatives responsible for championing the model of sustainability pursued by the actual community or institution [6,7]. One such environment is higher education, which constitutes a cultural legacy and has a major responsibility when integrating sustainability within its curricular development [8-12]; it is a framework that generates a very high socio-environmental impact [13]. In the same vein, the social perspective that higher education moves towards sustainability is a growing line of research in the scientific community [14]. To do so, higher education needs to use a specific methodology and understand the resources and contexts in which educational interactions take place; in other words, to understand that it is an essential part of a whole with a shared purpose, namely, meaningful learning based on motivation and engagement with the process.

The Camilo José Cela University in Madrid has as a reference the pedagogical model called "Intelligent Classroom", proposed 25 years ago by Segovia, Beltrán and Arias [15]. This paradigm defines education based on eight fundamental dimensions of the teaching-learning processes: (i) goals, (ii) task, (iii) methods, (iv) sequence, (v) teacher's role, (vi) student's role, (vii) evaluation and (viii) context. In the eighth dimension (context), the new environment learning (NEL) is integrated. It is named "Learning Lab" by its creator, a term that we ignored in this manuscript to avoid confusion with the methodology developed by Bal [16]. NEL is an environment different from the traditional classroom (TC), due to a remodeling of physical spaces and the adaptation of the environment to generate a pleasant, comfortable and friendly environment [17] and to support the teaching-learning processes that enhance personal development [18].

This is the backdrop for the NEL, an education project headed by the international expert Heppell [19], which is defined as an open space that favours reflection, discussion and the design of hands-on methodologies. The NEL was implemented in 2018 at Camilo José Cela University in Madrid. During construction, they considered aspects such as enhancing exterior views with natural light, adjustable artificial light [20], the height of the environment [21], the absence of physical barriers (open spaces) [22], surrounding the nature space $[23,24]$ and having mobile round tables for collaborative work that allow adaptation to a variety of learning approaches [25].

\section{State of Art: Learning Process Environments}

A recent World Bank report focused on the setting, or physical context, as a key feature of the NEL, and revealed the benefits of the facilities' physical aspects and design, which may affect academic performance [26], elements also highlighted by Zubrzycki [27] and Shamaki [28], or reduce dropout rates [29] due to a higher level of attention in the learning processes [30]. However, the importance of further research in this field was stressed [31]. Schneider [32] conducted a literature review of 137 sources and found that aspects such as noise, heat, cold, light and air quality impact upon the learning process. These results were in line with those obtained by Barrett, Zhang, Moffat and Kobbacy [33], which highlighted the positive effect of environmental conditions in a sample of 751 students from 34 primary and secondary schools. In turn, Woolner, Hall, Higgins, Mccaughey and Wall [34] also conducted a literature review of more than 200 sources and found clear evidence the environmental conditions affect learning.

In the same vein, the US National Research Council [35] analysed 392 sources related to ecological design, finding that a student's learning is positively affected by good indoor air quality, a comfortable temperature, good acoustics, well-maintained systems and clean surfaces. Davies, Jindal-Snape, Collier and Digby [36] reviewed 210 sources and stressed the importance of light, heat, sound and the microclimate for generating creativity, with the setting, flexibility and availability of resources also having a significant influence. In addition, they have highlighted the link between design features and teaching issues, which helps to motivate and avoid the disconnection of students [37]. 
Following an analysis of more than 100 sources, Bluyssen [38] stressed that design features affect the learning process, absenteeism and mainly health. Barrett, Zhang, Davies and Barrett [39] found that the physical characteristics of learning environments have a significant impact on a student's learning process and could explain up to $16 \%$ of variance. This impact was generated by good natural-light conditions, air quality, temperature regulation, acoustics, links to nature, easily navigable connected spaces that may provide additional learning experiences, and environmental stimuli through colour and visual complexity.

The physical environment in which the learning process takes place should also consider two main aspects: the physical layout and the actual environment generated. These aspects either restrict or enhance learning [40]. Participation is a mediating factor between these two aspects; a suitable infrastructure or a positive atmosphere serves no purpose unless there is reflexive thinking, autonomy, dialogue, assertiveness, empathy and other myriad aspects closely related to the educational process that provide a quality education permitting the assimilation of necessary skills and knowledge for a sustainable future [41].

Finally, we should note that the NEL setting and its benefits greatly favour education for sustainable development [42], as the actual environment and its proper use reinforce necessary aspects of learning, such as asking critical questions and learning to clarify one's own personal values, to imagine more positive and sustainable futures, to think in a systematic manner, to respond based on applied learning and, of course, to explore in pursuit of innovation [43], all of which are mediated by active participation as the enabler of the necessary social transformation toward more sustainable practices [44].

Furthermore, these processes are not, a priori, compatible with the TC model; in other words, a traditional environment that does not consider, as Bonell [40] contends, the physical setting and atmosphere as enablers of the learning process, although there is scant evidence of the development of students' competencies in sustainability $[45,46]$.

Based on the studies reviewed, which highlight the importance that the physical environment has on learning, and the innovative nature of the NEL setting, this study sought to analyse the possible differences across a series of learning-related variables that depended on whether students attended class in an NEL or in a TC. With regards to the initial hypothesis, higher scores were expected in the research variables in NEL than in TC.

With a view to responding to these questions, a study was conducted according to the experience sampling method. The aim of this method, which is considered highly innovative and recommendable in education research [47], was to evaluate a representative sample of self-reports on students' experiences in either type of classroom at the same time as they were taking place.

This methodology sought to evaluate the participants' experience at exactly the same moment as it was taking place (or at least, as close in time as possible, which meant as soon as the class ended) in order to minimise certain biases inherent to self-reporting, such as those arising from how people reconstruct their past experiences [48], and thereby record more reliable answers. Likewise, the experience sampling method enhances a study's reliability by adding statistical power by increasing the number of measurements per person, which strengthened our study's ability to detect the effects of interest without having to use a very large sample.

\section{Materials and Methods}

As shown in Table 1, the study's sample involved 33 university students ( 5 males, 28 females, average age $M=20.82, S D=2.93$, with ages ranging from 18 to 34) enrolled in degrees in Communication $(n=1)$, Education $(n=11)$ and Psychology $(n=21)$. Within each subject, the lecturer organized some session in NEL and some in TC. Depending on the lecturer they had during the study (all of whom taught in a NEL and in a TC), the participants were distributed as follows: Lecturer $1(n=4)$, lecturer 2 $(n=1)$, lecturer $3(n=11)$, lecturer $4(n=1)$ and lecturers 1 and $4(n=16)$. The students took part in the study on a voluntary basis and received a small mark-up in the subjects involved in the study. The study complied with the university's ethical standards. The participants were told about the study 
and were explained their rights (e.g., confidentiality, anonymity and the right to withdraw at any time without any form of reprisal), and they signed an informed consent form. Once the study had ended, they were explained the research goals.

Table 1. Sample distribution according to degree, sex and lecturer.

\begin{tabular}{ccccccc}
\hline & Lect. 1 & Lect. 2 & Lect. 3 & Lect. 4 & Lects. 1 and 4 & Total \\
\hline $\begin{array}{c}\text { Communication } \\
\text { Male }\end{array}$ & & & & & & 1 \\
$\quad$ Female & & 1 & & & & \\
Education & & & 1 & & & 11 \\
Male & & & 10 & & & \\
Female & & & & & & \\
Psychology & 1 & & & 1 & 13 & \\
Male & 3 & & & 11 & 16 & 33 \\
Female & 4 & 1 & 11 & 1 & \\
Total & & & & & \\
\hline
\end{tabular}

To evaluate a NEL's possible effects on certain variables related to the students' learning process, use was made of an intensive longitudinal design (or experience sampling method, focusing on a specific event in this case). In other words, the study variables were repeatedly evaluated in all the participants, specifically after each of the classes chosen for the study (in both a NEL and a TC, see Figure 1) over 53 days, obtaining a total of 359 responses in the TC and 209 in the NEL. The data were gathered by sending the participants a message to their mobile phones just before the end of the selected classes with a link to an online questionnaire that immediately assessed their experience in that class, which could correspond to a NEL or to a TC. Figure 2 shows the distribution of the NEL.

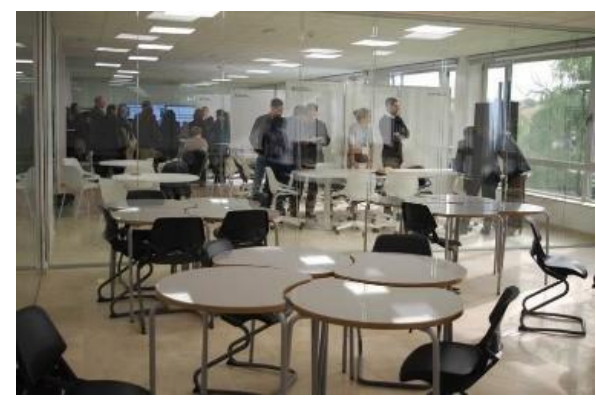

(a)

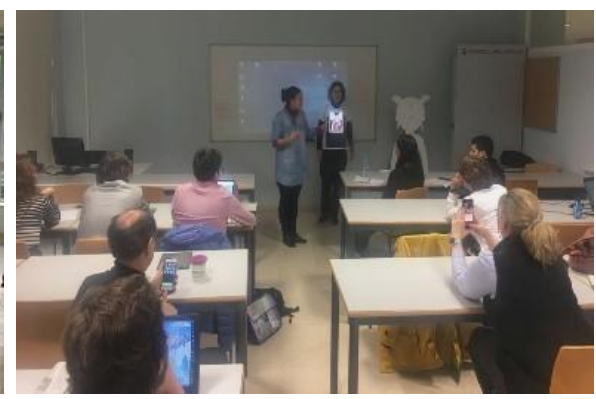

(b)

Figure 1. (a) New environment learning (NEL) and (b) traditional classroom (TC).

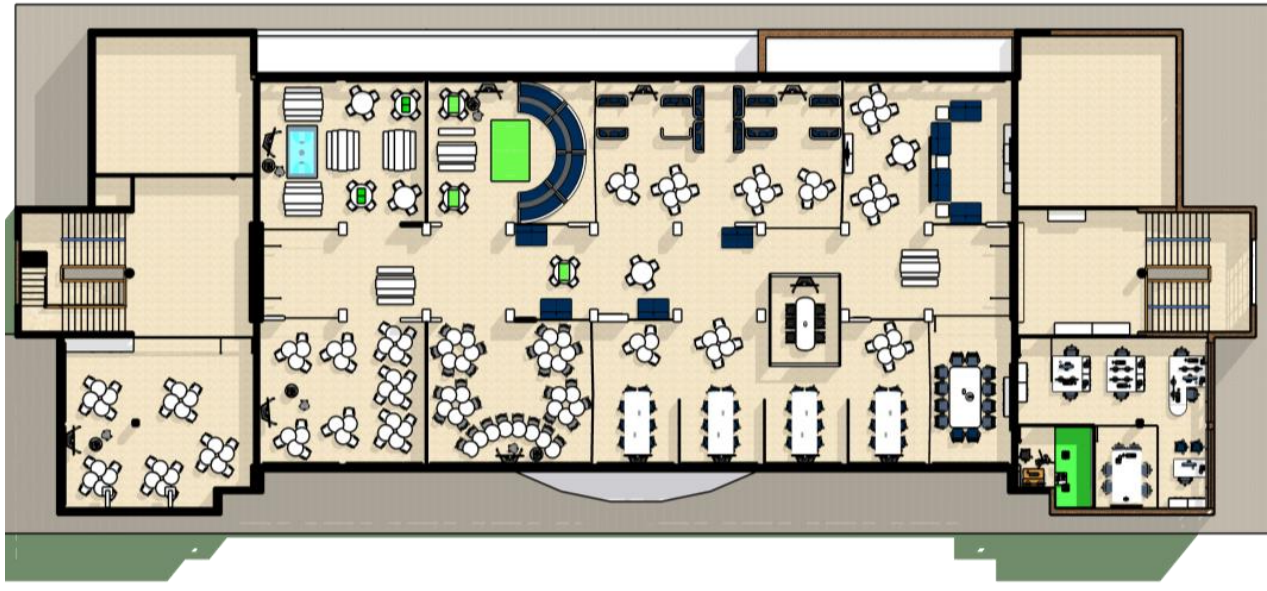

Figure 2. Layout of the new environment learning. 
This assessment covered the level of attention, the degree of participation in class, the degree of visual aesthetics perceived regarding the classroom, creativity, curiosity, critical thinking, motivation to learn and mood state (hedonic tone and level of activation). Table 2 lists the items specifically designed for this study, which assessed each one of these variables on a five-point Likert-type scale ranging from $1=$ Not at all to $5=$ Completely.

Table 2. Questionnaire used in the study.

\begin{tabular}{|c|c|}
\hline \multicolumn{2}{|c|}{$\begin{array}{l}\text { Instructions: Based on the Class You Have Just Had, Please Rate the Following } \ldots \\
\text { (Where } 1=\text { Not at All and } 5=\text { Completely) }\end{array}$} \\
\hline Variable & Question \\
\hline Attention & Have you found it easy to pay attention? \\
\hline Participation & Have you taken part in the class? \\
\hline Creativity & Have you had any new ideas? \\
\hline Curiosity & Has your curiosity been awoken? \\
\hline Critical thinking & $\begin{array}{c}\text { Have you thought about anything in depth, and have you } \\
\text { analysed it from different viewpoints? }\end{array}$ \\
\hline Motivation for learning & Has it prompted you to want to learn more about a topic? \\
\hline Mood state (valence) & Has it been a pleasant experience? \\
\hline Mood state (activation) & Do you feel energised? \\
\hline Visual appeal & The classroom is visually appealing? \\
\hline
\end{tabular}

\section{Results}

The data analysis was performed using SPSS version 22.0. Table 3 shows the descriptive statistics for the 33 students, as measured for all the variables on the questionnaire administered according to the type of classroom.

Table 3. Descriptive statistics.

\begin{tabular}{cccc}
\hline Dependent Variable & Type of Classroom & M & SD \\
\hline \multirow{2}{*}{ Attention } & TC & 3.48 & 0.72 \\
& NEL & 3.41 & 0.82 \\
Participation & TC & 2.89 & 1.15 \\
& NEL & 3.32 & 1.07 \\
Creativity & TC & 2.79 & 1.12 \\
& NEL & 2.98 & 0.88 \\
Curiosity & TC & 3.17 & 1.00 \\
& NEL & 2.94 & 0.96 \\
Critical thinking & TC & 2.86 & 0.94 \\
& NEL & 2.89 & 1.05 \\
Motivation for learning & TC & 3.11 & 1.02 \\
\multirow{3}{*}{ Mood state (valence) } & NEL & 2.90 & 1.00 \\
\multirow{2}{*}{ Mood state (activation) } & TC & 3.46 & 0.94 \\
Visual appeal & NEL & 3.45 & 0.87 \\
& TC & 3.11 & 1.09 \\
& NEL & 3.01 & 0.95 \\
& TC & 3.16 & 1.11 \\
& NEL & 3.64 & 1.04 \\
\hline
\end{tabular}

The assessment of the differences between the possible effects of the NEL and the TC on the study's dependent variables involved a repeated measures paired sample $t$-test, which compared the scores recorded by the 33 students in all the study variables, either in the NEL or in the TC. The results are reported in Table 4. 
Table 4. Paired sample $t$-test.

\begin{tabular}{|c|c|c|c|c|c|c|c|c|c|}
\hline \multicolumn{10}{|c|}{$\begin{array}{l}95 \% \text { Confidence } \\
\text { Interval of the } \\
\text { Difference }\end{array}$} \\
\hline $\begin{array}{c}\text { Pairs } \\
\text { (TC-NEL) }\end{array}$ & $\mathbf{M}$ & SD & $\begin{array}{l}\text { Mean Error } \\
\text { Deviation }\end{array}$ & Lower & Upper & $t$ & gl & $\begin{array}{c}\text { Sig. } \\
\text { (Bilateral) }\end{array}$ & $\begin{array}{l}\text { Effect Size } \\
\text { (Cohen's d) }\end{array}$ \\
\hline Attention & 0.060 & 0.796 & 0.138 & -0.221 & 0.343 & 0.438 & 32 & 0.664 & 0.087 \\
\hline Participation & -0.423 & 1.089 & 0.189 & -0.809 & -0.037 & -2.232 & 32 & 0.033 & 0.398 \\
\hline Creativity & -0.184 & 1.057 & 0.184 & -0.558 & 0.190 & -1.000 & 32 & 0.325 & 0.189 \\
\hline Curiosity & 0.234 & 0.705 & 0.122 & -0.015 & 0.484 & 1.908 & 32 & 0.065 & 0.235 \\
\hline $\begin{array}{l}\text { Critical } \\
\text { thinking }\end{array}$ & -0.035 & 0.719 & 0.125 & -0.290 & 0.219 & -0.285 & 32 & 0.777 & 0.030 \\
\hline $\begin{array}{l}\text { Motivation } \\
\text { for learning }\end{array}$ & 0.208 & 0.745 & 0.129 & -0.055 & 0.473 & 1.610 & 32 & 0.117 & 0.208 \\
\hline $\begin{array}{l}\text { Mood state } \\
\text { (valence) }\end{array}$ & 0.008 & 0.986 & 0.171 & -0.341 & 0.358 & 0.048 & 32 & 0.962 & 0.011 \\
\hline $\begin{array}{l}\text { Mood state } \\
\text { (activation) }\end{array}$ & 0.100 & 1.067 & 0.185 & -0.277 & 0.479 & 0.542 & 32 & 0.592 & 0.095 \\
\hline Visual appeal & -0.482 & 1.241 & 0.216 & -0.923 & -0.042 & -2.235 & 32 & 0.032 & 0.446 \\
\hline
\end{tabular}

The results recorded statistically significant differences in two dimensions. In terms of the degree of participation, there were statistically significant differences $(t(32)=2.23, p=0.033, d=0.398)$, with a moderate effect size, whereby the students in the NEL recorded higher scores $(M=3.32, \mathrm{SD}=1.07)$ than the students in the TC $(M=2.89, \mathrm{SD}=1.15)$, which means that students considered they were more involved in the NEL than in the TC.

On the other hand, statistically significant differences were also found in the visual appeal perceived by the students in the classroom $(t(32)=2.24, p=0.032, d=0.446)$, with a moderate effect size, whereby the students in the NEL recorded higher scores $(M=3.64, \mathrm{SD}=1.04)$ than in the TC $(M=$ $3.16, \mathrm{SD}=1.11$, which means that the students found the NEL aesthetically more pleasing than the TC. No statistically significant differences were found in any of the other dimensions. Figures 3 and 4 show the differences between the TC and the NEL in terms of participation and degree of visual appeal.

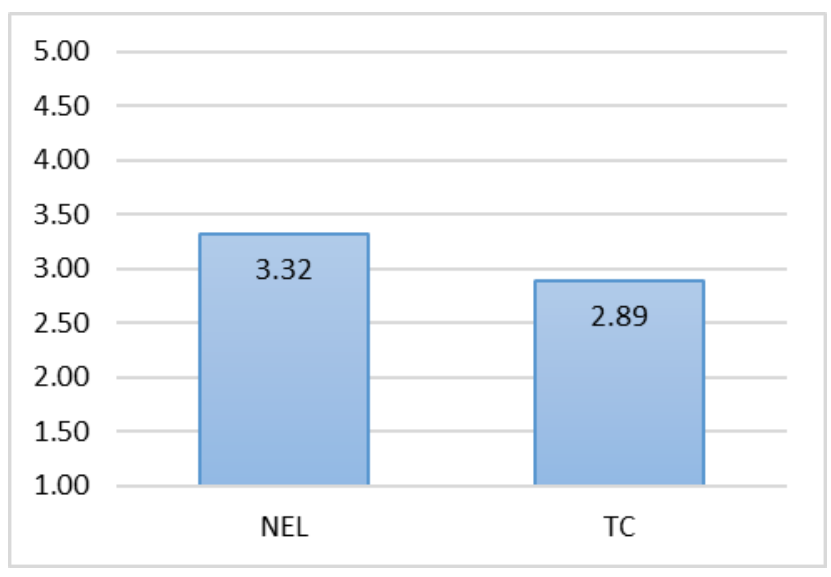

Figure 3. Differences in the level of participation between the TC and the NEL. 


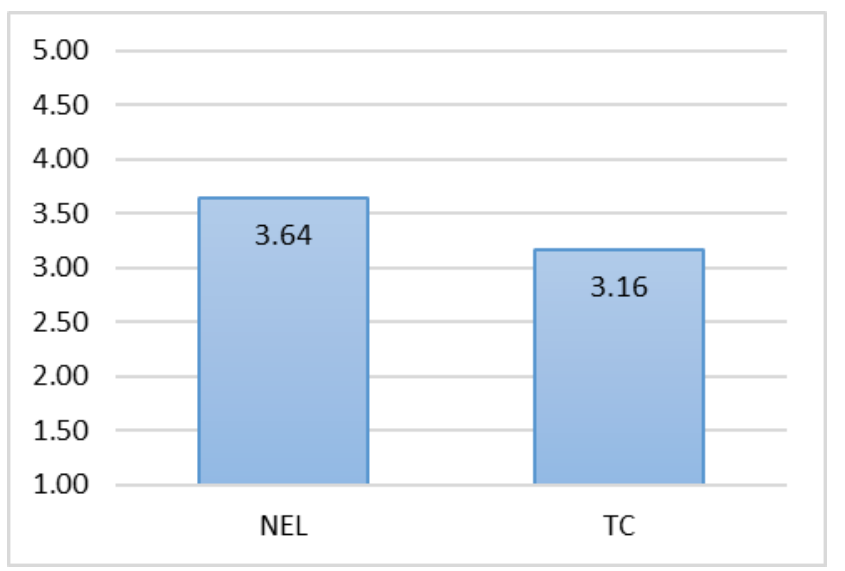

Figure 4. Differences in the level of visual appeal perceived between the TC and the NEL.

\section{Discussion}

The results obtained partially ratify our hypothesis, as the students in the NEL recorded a higher participation than their peers in the TC, where the space and conditions favoured greater interaction. These results are consistent with the observations recorded by Woolner, Hall, Higgins, Mccaughey and Wall [34], Schneider [32], Zubrzycki [27], Shamaki [28] and Barrett, Zhang, and Moffat y Kobbacy [33], who found that environmental aspects, such as noise, heat, cold, light and air quality affect the learning process, with participation being a major factor in its success. Our results about the positive effect of open spaces in learning are also consistent with those observed by Gilavand and Espidkar y Gilavand [49], or Scott-Webber, Strickland and Ring Kapitula [50], who conducted a study at four US universities and found that most of the students surveyed gave a higher rating to the design of a nontraditional classroom (open-plan layout rather than a cellular arrangement) influencing factors such as collaboration, participation, physical movement and the creation of an enriching experience. These results are in line with the principles defining the innovative learning environments proposed by the Organisation for Economic Co-operation and Development (OECD) [51], one of which establishes that these settings should be based on the social nature of learning and should foster teamwork and peer learning. All these data show how this novel environment [45] helps learning processes.

We should not forget that education for sustainable development requires a transformative-type pedagogy, one geared towards action that favours both participative learning and interpersonal and group learning among its members [52-54] in order to acquire the tools that pave the way for hands-on involvement in society. In turn, these premises coincide with that competency of conformity, or Gestaltungskompetenz, highlighted by De Haan [55], which acts as a framework competency in sustainability that allows problem-solving and direct action on difficulties, and which in turn encompasses several subcompetencies where participatory skills are essential.

On the other hand, the achievement of hands-on involvement also means a change in approach when understanding and developing the teaching-learning process [56]. It is precisely that change that the NEL seeks to effect: to modify educational interaction based on the context, whereby students encounter a suitable learning climate, an environment where they feel active members of the educational community, based on a series of rights and responsibilities [54] for favouring a more sustainable lifestyle.

The figure of the teacher/lecturer is also crucial for achieving a participatory process that leads to quality, sustainable and critical education [57], where those who work in satisfactory spatial conditions have more positive attitudes than those that do so in unsuitable facilities [58], thereby playing a vital role in interactions and opportunities for discussion. These factors have already been addressed by scholars in classical educational psychology, such as Ausubel [59]. As we have already noted in the introduction, the NEL itself works thanks to the teacher's pivotal role, acting as mentor, mediator and promotor for the students' required involvement, with a view to understanding the problems existing in the environment, their possible solutions [60] and the way of engaging with the world. All this is 
possible if we overcome approaches that still use antiquated teaching methods [61], and if we focus on interaction and relationships with others in an environment shaped by information, knowledge and new technologies [62] that enable students to live according to their more progressive beliefs and values, together with the mastery of new ways of gaining knowledge [42].

In conclusion, this study shows how the students rated the NEL as visually more attractive than the TC. These results coincide with the studies by Plass, Heidig, Hayward, Homer and Um [63], in which they reported that visually attractive objects are considered more valuable and reliable, and the perceived value of this is important for young adults. They are also consistent with the research by Heidig, Müller and Reichelt [64], which reported how a visually attractive setting favours positive emotions, which may in turn foster an intrinsic motivation to learn. The NEL stands in contrast to the traditional lack of interest in considering an educational institution as a visually aesthetic setting [65], where the environment's sensitive values are often ignored [66] or there is a major restriction on the ability to use the senses in an unfettered and creative manner, even though they might help to make the learning process more effective [67]. Education for sustainable development calls for the care and appreciation of the environment with which it converges [43], leading us to highlight this result yet further still, as within the same learning process the aim is for the context to become a meaningful component in aesthetic terms for favouring attractive and pleasant learning environments [68,69].

In regards to the absence of statistically significant differences in all the other study variables, one possible explanation is that the NEL is a new feature in our university, and this is the first year in which the lecturers are using it. This change may also have prompted certain initial misgivings among teaching staff because of their lack of knowledge and user experience. Making the most of the NEL may call for the provision of more staff training in the numerous methodologies that this type of classroom caters for (such as project-based learning, gamification and service-learning). Although advances have been made in educational environments and technologies, as well as in the way students have adapted to their changing scenarios, many lecturers still use outdated teaching methods [70]. In fact, recent reviews on longitudinal case studies [71] described the situation of five secondary schools in the UK, four of which were built with an open-plan layout as part of the UK programme Building Schools for the Future in 2003-2010, while a lack of budget meant that one school retained its old facilities. The results of these studies show that the school at which the staff and methods reflected the new facilities performed well, whereas those schools in which the staff did not share the educational approach or use methods that did not fit in with the new open areas encountered several issues. In turn, the sole school that kept its old buildings found it difficult to introduce the new teaching approach because of the actual structure of their facilities. These cases reveal the importance of ensuring consistency between physical areas and the teaching methods used in them. This means that future studies should explore these issues, including the teaching methods used and whether there have been any changes since they started teaching in new premises. These future studies should perhaps be studied using qualitative methods, such as focus groups or interviews with the faculty members involved, whereby we can respond to their needs and help them adapt to the new learning scenarios, as well as furnish them with the tools required to fully exploit these facilities.

One of this study's possible limitations also concerned the type of subjects involved. Because of their actual content, some of them may not have fostered some of the variables we measured, such as creativity. This means that future studies should include more subjects and more varied ones regarding their possible relationship with driving the study variables. Another possible limitation was the evaluation used. Given the number of variables evaluated and the immediate nature of the process conducted here- - that is, as soon as the class ended, we decided to evaluate each dependent variable with a single item-there may have been a loss of reliability in the measure. Future studies should therefore focus on fewer variables, albeit with more items for each one of them, with a view to increasing the measures' reliability. This will also have a knock-on effect on the variability of the answers, together with the probability of finding statistically significant differences. Another way of increasing the answers' variability may be to increase the measure's response scale. In addition, we 
use only self-report measures. Future studies might also include more objective measures, such as the marks awarded in the subjects or some performance assignment.

A further limitation was that although the design of the new facilities at our university had considered aspects such as appropriate levels of light, acoustics or temperature for learning, in this study we did not check that these factors effectively fulfilled the target parameters. It should also be noted that these factors needed to be evaluated in a joint manner, as the reality might be that some aspects of the area "competed" with others. For example, our university's geographical location means that a comfortable temperature at certain times of the year might require shielding the classrooms from the sun by using blinds, thereby reducing the optimal levels of natural daylight.

Finally, we did not control for the effects on learning that would correspond to the students and the lecturer, which were estimated to account for $30 \%$ and $50 \%$ of the variance, respectively [72,73]. Future studies involving a larger and more varied sample could conduct a multilevel analysis that would enable us to separate the effects due to the students' characteristics from those corresponding to the class and their knowledge and competences obtained, as well as from those due to the characteristics of lecturers and their teaching practices.

In short, our study takes a step forward in the research into educational environments, showing that the physical setting in itself may have certain positive effects on specific aspects related to learning, providing a reflection on which ones may be important for optimising the teaching-learning process in these innovative facilities; topics that we trust future studies will address in order to continue advancing in this highly necessary line of research.

Author Contributions: Conceptualization, D.G.-C., A.M., M.L.M.-M. and M.Á.P.-N.; data curation, A.M. and M.L.M.-M.; formal analysis, A.M., M.L.M.-M. and M.Á.P.-N.; methodology, A.M., M.L.M.-M. and M.Á.P.-N.; project administration, M.Á.P.-N.; visualization, A.M. and M.L.M.-M.; writing—original draft, D.G.-C., A.M., M.L.M.-M. and M.Á.P.-N.; writing-review and editing, D.G.-C., A.M., M.L.M.-M. and M.Á.P.-N. All authors have read and agreed to the published version of the manuscript.

Funding: This research received no external funding.

Acknowledgments: We are grateful to the Educational Institution SEK, to the faculty members and students involved in the study and to Eduardo Corral for his support in the data collection.

Conflicts of Interest: The authors declare no conflict of interest.

\section{References}

1. UNESCO. Education for Sustainable Development Goals. Learning Objectives; UNESCO: Paris, France, 2017. Available online: http://unesdoc.unesco.org/images/0024/002474/247444e.pdf (accessed on 20 March 2020).

2. Delors, J. La educación encierra un tesoro. Informe a la unesco de la Comisión Internacional de la educación para el siglo XXI; Santillana/unesco: Madrid, Spain, 1996.

3. Ander-Egg, E. La planificación educativa: conceptos, métodos, estrategias y técnicas para educadores; Magisterio del Rio de la Plata: Buenos Aires, Argentina, 1996.

4. Escudero, J.M. Fracaso escolar, exclusión educativa: ¿De qué se excluye y cómo? Profr. Rev. Currículum Form. Profr. 2005, 1, 1-24.

5. Vallcorba, J. Planes educativos. Cuad. Pedagog. 2008, 375, 50-53.

6. Ryan, A. Education for Sustainable Development and Holistic Curriculum Change: A Review and Guide; HEA: New York, NY, USA, 2011. Available online: http://www.heacademy.ac.uk/assets/documents/esd/ESD_Artwork_ 050412_1324.pdf (accessed on 20 March 2020).

7. Winter, J.; Cotton, D. Making the hidden curriculum visible: sustainability literacy in higher education. Environ. Educ. Res. 2012, 18, 783-796. [CrossRef]

8. Cebrián, G.; Pascual, D.; Moraleda, A. Perception of sustainability competencies amongst Spanish pre-service secondary school teachers. Int. J. Sustain. High. Educ. 2019, 20, 1171-1190. [CrossRef]

9. Cebrián, G. The I3E model for embedding education for sustainability within higher education institutions. Environ. Educ. Res. 2018, 24, 153-171. [CrossRef] 
10. Rammel, C.; Velazquez, L.; Mader, C. Sustainability Assessment in Higher Education Institutions-What and how? In Routledge Handbook of Higher Education for Sustainable Development; Barth, M., Michelsen, G., Rieckmann, M., Thomas, I., Eds.; Routledge International Handbooks: London, UK, 2015; pp. 331-346.

11. Mader, C.; Scott, G.; Razak, D.A. Effective change management, governance and policy for sustainability transformation in higher education. Sustain. Account. Manag. Policy J. 2013, 4, 264-284. [CrossRef]

12. Pereyra, M.A.; Luzón, A.; Sevilla, D. Las universidades españolas y la construcción del Espacio Europeo de Educación Superior. Limitaciones y perspectivas de cambio. Rev. Española Educ. Comp. 2006, 12, 113-144.

13. Castro, R.; Jabbour, C. Evaluating sustainability of an Indian university. J. Clean. Prod. 2013, 61, 54-58. [CrossRef]

14. Lambrechts, W.; Platje, J.; Van Dam, Y.K. Guest editorial: The university as an arena for sustainability transition. Int. J. Sustain. High. Educ. 2019, 20, 1101-1108. [CrossRef]

15. Segovia, F.; Beltrán, J.A.; Martínez, M.R. El Aula inteligente, una experiencia educativa innovadora. Rev. Española Pedagog. 1999, 57, 83-109.

16. Bal, A. Culturally Responsive School-Wide Positive Behavioral Interventions and Supports Framework; Wisconsin Department of Public Instruction: Madison, WI, USA, 2011.

17. Fernández Enguita, M. Más Escuela y Menos Aula; Morata: Madrid, Spain, 2018.

18. Segovia, F. (Dir.). El aula Inteligente. Nuevas Perspectivas; Espasa Calpe: Madrid, Spain, 2003.

19. Mokhtar Noriega, F.; Jiménez Rodríguez, M.A.; Heppell, S.; Segovia Bonet, N. Creando espacios de aprendizaje con los alumnos para el tercer milenio. Bordón 2016, 68, 61-68. [CrossRef]

20. Tanner, C.K. The Interface Among Educational Outcomes and School Environment. Educ. Plan. 2014, 21, $19-28$.

21. Zhu, R.; Meyers Levy, J. The influence of self view on context effects: How display fixtures can affect product evaluations. J. Mark. Res. 2009, 46, 37-45. [CrossRef]

22. Sternberg, E.M.; Wilson, M.A. Neuroscience and Architecture: Seeking Common Ground. Cell 2006, 127, 239-242. [CrossRef]

23. Keniger, L.E.; Gaston, K.J.; Irvine, K.N.; y Fuller, R.A. What are the Benefits of Interacting with Nature? Int. J. Environ. Res. Public Health 2013, 10, 913-935. [CrossRef]

24. Wells, N.M. The Role of Nature in Children's Resilience: Cognitive and Social Processes. In Greening in the Red Zone: Disaster, Resilience and Community Greening; Tidball, K.G., Krasny, M.E., Eds.; Springer: Dordrecht, The Netherlands, 2014; pp. 95-109.

25. Valenti, M. Beyond active learning: Transformation of the learning space. Educ. Rev. 2015, 50, 31-38.

26. Blincoe, J.M. The Age and Condition of Texas High Schools as Related to Student; The University of Texas at Austin: Austin, TX, USA, 2008.

27. Zubrzycki, J. Schools' Design Can Play Role in Safety, Student Engagement. Educ. Week 2013, 32, 32.

28. Shamaki, T.A. Influence of Learning Environment on Students' Academic Achievement in Mathematics: A Case Study of Some Selected Secondary Schools in Yobe State-Nigeria. J. Educ. Pract. 2015, 6, 40-44.

29. Branham, D. The wise man builds his house upon the rock: The effects of inadequate school building infrastructure on student attendance. Soc. Sci. Q. 2004, 85, 1113-1128. [CrossRef]

30. Yeung, A.S.; Craven, R.G.; Kaur, G. Teachers' self-concept and valuing of learning: Relations with teaching approaches and beliefs about students. Asia-Pac. J. Teach. Educ. 2014, 42, 305-320. [CrossRef]

31. Barrett, P.; Treves, A.; Shmis, T.; Ambasz, D.; y Ustinova, M. The Impact of School Infrastructure on Learning: A Synthesis of the Evidence. International Development in Focus; World Bank Group: Washington, DC, USA, 2019.

32. Schneider, M. Do School Facilities Affect Academic Outcomes; Educational Resources Information Center, United States Department of Education: Washington, DC, USA, 2002.

33. Barrett, P.; Zhang, Y.; Moffat, J.; Kobbacy, K. A holistic, multi-level analysis identifying the impact of classroom design on pupils' learning. Build. Environ. 2013, 59, 678-689. [CrossRef]

34. Woolner, P.; Hall, E.; Higgins, S.; Mccaughey, C.; Wall, K. A Sound Foundation? What We Know about the Impact of environments on learning and the Implications for Building Schools for the Future. Oxf. Rev. Educ. 2007, 33, 47-70. [CrossRef]

35. US National Research Council. Green Schools: Attributes for Health and Learning. Committee to Review and Assess the Health and Productivity Benefits of Green Schools; The National Academies Press: Washington, DC, USA, 2006. 
36. Davies, D.; Jindal-Snape, D.; Collier, C.; Digby, R. Creative learning environments in education: A Systematic literature review. Think. Skills Creat. 2013, 8, 80-91. [CrossRef]

37. Kariippanon, K.E.; Cliff, D.P.; Lancaster, S.J.; Okely, A.D.; Parrish, A.M. Flexible learning spaces facilitate interaction, collaboration and behavioural engagement in secondary school. PLOS ONE 2019, 14, 1-13. [CrossRef] [PubMed]

38. Bluyssen, P.M. Health, comfort, and performance of children in classrooms: New directions for research. Indoor Built Environ. 2016, 26, 1040-1050. [CrossRef]

39. Barrett, P.S.; Zhang, Y.; Davies, F.; Barrett, L. Clever Classrooms: Summary Report of the HEAD Project; University of Salford: Salford, UK, 2015.

40. Bonell, M.P. El aula Escolar, Escenario Propicio Para Gestionar una Cultura Para Prevención de Desastres; Alcaldía Mayor y Dirección de Prevención y Atención de Emergencias Secretaría de Gobierno: Bogotá, CO, USA, 2003.

41. Giangrande, N.; White, R.M.; East, M.; Jackson, R.; Clarke, T.; Saloff Coste, M.; Penha-Lopes, G. A Competency Framework to Assess and Activate Education for Sustainable Development: Addressing the UN Sustainable Development Goals 4.7 Challenge. Sustainability 2019, 11, 2832. [CrossRef]

42. Burmistrova, N.A.; Vasina, N.V.; Filimonov, V.A.; Kalnitskaya, I.V.; Shmakova, A.P.; Ilina, N.I. The Concept of Smart-Education for Sustainable Development. Adv. Soc. Sci. Educ. Humanit. Res. 2018, 198, 192-196. [CrossRef]

43. Tilbury, D. Education for Sustainable Development: An Expert Review of Processes and Learning; UNESCO: Paris, France, 2011. Available online: http://unesdoc.unesco.org/images/0019/001914/191442e.pdf (accessed on 20 March 2020).

44. Barth, M.; Godemann, J.; Rieckmann, M.; Stoltenberg, U. Developing key competencies for sustainable development in higher education. Int. J. Sustain. High. Educ. 2007, 8, 416-430. [CrossRef]

45. Cebrián, G.; Fernández, M.; Fuertes, M.; Moraleda, A.; Segalàs, J. La influencia del Aprendizaje-Servicio en el desarrollo de competencias en sostenibilidad en estudiantes universitarios. Bordón. Rev. Pedagog. 2019, 71, 151-167. [CrossRef]

46. Wiek, A.; Withycombe, L.; Redman, C.L. Key competencies in sustainability: A reference framework for academic program development. Sustain. Sci. 2011, 6, 203-218. [CrossRef]

47. Zirkel, S.; García, J.A.; Murphy, M.C. Experience- sampling research methods and their potential for educational research. Educ. Researcher. 2015, 44, 7-16. [CrossRef]

48. Kahneman, D.; Krueger, A.B. Developments in the Measurement of Subjective Well-Being. J. Econ. Perspect. 2006, 20, 3-24. [CrossRef]

49. Gilavand, A.; Espidkar, F.; Gilavand, M. Investigating the impact of schools' open space on learning and educational achievement of elementary students. Int. J. Pediatrics 2016, 4, 1663-1670. [CrossRef]

50. Scott-Webber, L.; Stickland, A.; Ring Kapitula. A.Built Environments Impact Behaviours: Results of an Active Learning Post-Occupancy Evaluation. Plan. High. Educ. J. 2013, 42, 1-12.

51. OECD. Innovative Learning Environments. Educational Research and Innovation; OECD: París, France, 2013.

52. Jormanainen, I.; Toivonen, T.; Nivalainen, V. A smart learning environment for environmental education. In Challenges and Solutions in Smart Learning; Chang, M., Popsecu, E., Kinshuk, N., Chen, S., Jemni, M., Huang, R., Spector, J.M., Eds.; Springer: Singapore, 2018; pp. 13-16.

53. Cebrián, G.; Junyent, M.; Mulà, I. Competencies in Education for Sustainable Development: Emerging Teaching and Research Developments. Sustainability 2020, 12, 579. [CrossRef]

54. López-Alcarria, A.; Olivares-Vicente, A.; Poza-Vilches, F. A Systematic Review of the Use of Agile Methodologies in Education to Foster Sustainability Competencies. Sustainability 2019, 11, 2915. [CrossRef]

55. De Haan, G. The BLK '21'programme in Germany: A 'Gestaltungskompetenz'-based model for Education for Sustainable Development. Environ. Educ. Res. 2006, 12, 19-32. [CrossRef]

56. Fischer, D.; Barth, M. Key Competencies for and beyond Sustainable Consumption: An Educational Contribution to the Debate. GAIA Ecol. Perspect. Sci. Soc. 2014, 23, 193-200. [CrossRef]

57. Didham, R.J.; Ofei-Manu, P. Advancing Policy to achieve Quality Education for Sustainable Development. In Issues and Trends in Education for Sustainable Development; Leicht, A., Heiss, J., Byun, W.J., Eds.; UNESCO: París, France, 2018; pp. 87-110.

58. Earthman, G.I.; Lemasters, L.K. Teacher attitudes about classroom conditions. J. Educ. Adm. 2009, 47, 323-335. [CrossRef]

59. Ausubel, D. Psicología Educativa. Un Punto de Vista Cognoscitivo; Trillas: Mexico City, Mexico, 1981. 
60. Dai, Y.; Hwang, S.H. Technique, Creativity, and Sustainability of Bamboo Craft Courses: Teaching Educational Practices for Sustainable Development. Sustainability 2019, 11, 2487. [CrossRef]

61. Hoel, T.; Mason, J. Standards for smart education-Towards a development framework. Smart Learn. Environ. 2018, 5, 3. [CrossRef]

62. Gee, J.P. Lo que nos Enseñan los Videojuegos Sobre el Aprendizaje y el Alfabetismo; Aljibe: Málaga, Spain, 2008.

63. Plass, J.; Heidig, S.; Hayward, E.; Homer, B.; Um, E. Emotional design in multimedia learning: Effects of shape and color on affect and learning. Learn. Instr. 2014, 29, 128-140. [CrossRef]

64. Heidig, S.; Müller, J.; Reichelt, M. Emotional design in multimedia learning: Differentiation on relevant design features and their effects on emotions and learning. Comput. Hum. Behav. 2015, 44, 81-95. [CrossRef]

65. Errázuriz-Larraín, L.H. (Ed.) El (f)actor Invisible; Consejo Nacional de la Cultura y las Artes: Santiago de Chile, Chile, 2015.

66. Porcher, L. La Educación Estética: Lujo o Necesidad; Editorial Kapelusz: Buenos Aires, Argentina, 1975.

67. Adu-Agyem, J.; Enti, M. Learning: the role of aesthetics in education. J. Sci. Technol. 2009, 29, 161-168. [CrossRef]

68. Castro Pérez, M.; Morales Ramírez, M.E. Los ambientes de aula que Promueven el aprendizaje, desde la perspectiva de los niños y niñas escolares. Rev. Electrón. Educ. 2015, 19, 1-32. [CrossRef]

69. Hoyuelos, A. Estrategias constructivas espaciales en la escuela. In Territorios de la infancia. Diálogos entre la Arquitectura y la Pedagogía; Cabanellas, I., Eslava., C., Eds.; Editorial Graó: Barcelona, Spain, 2005; pp. 175-180.

70. Singh, A.D.; Hassan, M. In Pursuit of Smart Learning Environments for the 21st Century; Current and Critical Issues in Curriculum Series, No. 12; UNESCO: Geneva, Switzerland, 2017.

71. Daniels, H. Continuity and Conflictin School Design: A Case Study from Building Schools for the future. Intell. Build. Int. 2015, 7, 64-82. [CrossRef]

72. Hattie, J. Visible Learning: A Synthesis of Over 800 Meta-Analyses Relating to Achievement; Routledge: New York, NY, USA, 2008.

73. Nye, B.; Konstantopoulos, S.; Hedges, L.V. How large are teacher effects? Educ. Eval. Policy Anal. 2004, 26237-26257. [CrossRef] 